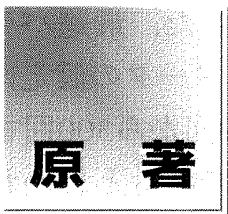

月5日

論文受理

2001年6月13日

Code No. 332

\section{心筋gated SPECTにおけるOSEM法の検討 一再構成条件の最適化一}

\author{
柳沢正道・ 丸 繁勘
}

千葉県循環器病センタ一放射線科

\section{緒 言}

近年の心臟核医学検查は，装置の進歩と，大量投与 が可能でイメージングに適した ${ }^{99 \mathrm{~m}} \mathrm{Tc}$ 標識製剂の開発 により，画質の優れたgated SPECTが短時間で収集可 能となっている。さらにGermanoらによって開発され たquantitative gated SPECT(QGS) $)^{1 ー 3}$ は, 簡便で再現 性良く心機能の定量評価を行えることから急速に普及 している. QGSは心筋血流に加え左室の拡張末期容量 $(\mathrm{EDV})$, 収縮末期容量 $(\mathrm{ESV})$, 心駆出率 (EF)の算出 が可能である。しかし胆囊に高集積が存在する場合，
ストリークアーチファクトが出現し，画質および定量 值に少なからず影響を及ばすことがある。このアーチ ファクトは, filtered back projection (FBP) 法の再構 成原理に起因古るものであり ${ }^{4-6)}$, 逐次近似再構成法 の臨床応用が待ち望まれていた。

近年，データ処理装置の高速化とordered subsets expectation maximization (OSEM) 法7の開発により, 逐次近似法の利用が日常の臨床に応用可能となりつつ ある。OSEM法によりアーチファクトを大幅に軽減す ることが可能である8-10)。しかしながら，OSEM法に

\title{
Study of the OSEM Algorithm in Myocardial Gated SPECT: Optimization of Reconstruction Parameters
}

\author{
MASAMICHI YANAGISAWA and SHIGENORI MARU \\ Department of Radiology, Chiba Cardiovascular Center Hospital \\ Received Apri1 5, 2001; Revision accepted June 13, 2001; Code No. 332
}

\section{Summary}

In order to use the ordered subsets expectation maximization(OSEM) algorithm for reconstruction of myocardial gated SPECT using ${ }^{99 \mathrm{~m}} \mathrm{Tc}$ myocardial agents, we evaluated the optimal reconstruction parameters in phantom and clinical studies. Since processing time increases in proportion to iteration number, as few iteration numbers as possible is desirable. From the results of left ventricular $(\mathbf{L V})$ volume and normalized mean square error (NMSE) in the phantom study, we concluded that the optimal number of iterations and subsets were 2 and 15, respectively, and the most suitable cutoff frequency of the Butterworth filter was 0.438 cycles/cm. LV volume estimated using the OSEM algorithm was less than that using the filtered back projection (FBP)algorithm. In the clinical study, the correlation coefficients of end-diastolic volume (EDV), end-systolic volume (ESV), and ejection fraction (EF) estimated by the OSEM algorithm were 0.99 $(\mathrm{p}<0.001), 0.97(\mathrm{p}<0.001)$, and $0.96(\mathrm{p}<0.001)$, respectively. A strong correlation was observed between the results of the two methods.

Key words: Ordered subsets expectation maximization (OSEM) algorithm, Myocardial gated single photon emission computed tomography (SPECT), Filtered back projection (FBP) algorithm, Left ventricular (LV) volume, Normalized mean square error (NMSE) 
よる再構成時に必要となる逐次近似回数とサブセット 数の二つのパラメータは, 前処理フィルタとともに定 量值に大きな影響を及ぼし，適切な值を選択すること が重要である。

そこでわれわれは，99mTc-テトロフォスミンを用い たgated SPECTにおいて, OSEM法の最適パラメータ を求めるため，ファントムにより基礎的実験を行うと ともに，臨床例においてQGSにより得られた定量值の FBP法との比較検討を行った。

\section{1. 方 法}

心臓ファントム〔株式会社京都科学社製RH-2(HL) 型了を使用し，左室心筋部分に7.4MBq ${ }^{99 \mathrm{~m}} \mathrm{Tc}$ 水溶液を 封入した。心内腔容積の実測值は $95 \mathrm{ml} ゙$ あった。 3 検 出器回転型カメラ (株式会社東芝製GCA9300A/UI)に 低エネルギー高分解能 (LEHR)コリメータを装着し, マトリクスサイズ $64 \times 64$ (ピクセルサイズ $6.4 \mathrm{~mm}$ ), RR分割数 16 , 収集角度 $6^{\circ}$, 収集時間60秒/ステップにて 収集を行った。散乱補正はtriple energy window (TEW) 法にて行い吸収補正は行っていない。

\section{1-1 処理時間の計測}

20スライスの再構成に要するFBP法およびOSEM法 の再構成時間を計測した. 対象データは正常モデルの ファントム収集データ(マトリクスサイズ $64 \times 64,960$ フレーム)である。雨再構成法とも前処理フィル夕を 使用し, OSEM法の再構成パラメータは逐次近似回数 を1，2，3，5，10，サブセット数を1，2，3，5， $10 ， 15 ， 20$ と変化させて再構成を行った。使用したデ 一夕処理装置のCPUはSUN UltraSPARC (クロック周 波数 $167 \mathrm{MHz}$, モモ128MB)である.

\section{1-2 逐次近似回数，サブセット数の検討}

FBP法の再構成は前処理フィルタにButterworthフィ ルタ (オーダ 8, カットオフ㓮波数 $0.391 \mathrm{cycle} / \mathrm{cm})$, 再 構成フィルタはRampフィルタを使用した。 OSEM法 の逐次近似回数とサブセット数は1-1と同様に変化さ せた。

\section{1-2-1 心內腔容積の測定}

正常モデル心筋ファントム，およびFig. 1に示すご とく, $3 \mathrm{~cm} \times 4 \mathrm{~cm}$ のシリコンゴム製の久損を下壁部分 に固定した下壁欠損モデル心筋ファントムにおいて， 前処理フィルタを用いずに画像再構成を行った場合, 正常モデル心筋ファントムにてFBP法と同様に Butterworthフィルタ（オーダ 8, カットオフ周波数 $0.391 \mathrm{cycle} / \mathrm{cm})$ を用いて再構成を行った場合の 3 パ夕 ーンに拈いて, QGSにより心内腔容積を算出した。

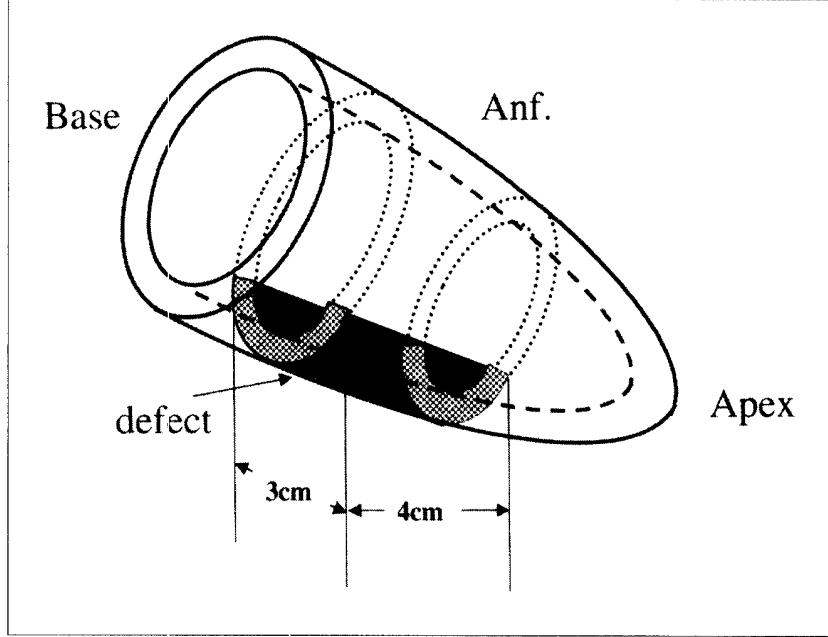

Fig. 1 Inferior defect model myocardial phantom.

\section{1-2-2 normalized mean square error(NMSE)によ る評価}

NMSEの)基準画像としては統計ノイズを無視できる よう十分に時間をかけて収集した画像を用いるのが一 般的ではあるが，分割によりもともと1フレーム当た りのカウント数が少ないgated SPECTの性質, および OSEM法を臨床応用することを重視し，現状でルーチ ン検查に朋いている，Butterworthフィルタ（オーダ 8, カットオフ周波数 $0.391 \mathrm{cycle} / \mathrm{cm}) に て$ 前処理を行 い，Rampフィルタにて再構成を行った画像を基準画 像とした。FBP法により再構成された短軸画像を基準 とし, OSEM法の各パラメータごとの画像について, 次式によりNMSEを算出した。

$$
\operatorname{NMSE}(\%)=\sqrt{\frac{\sum_{i, j}^{n}(p(i, j)-q(i, j))^{2}}{\sum_{i, j}^{n} q(i, j)^{2}}} \times 100
$$

$p(i, j)$ : 基準画像

$p(i, j)$ : 観測画像

$n$ : 画像のピクセル数

\section{1-3 前処理フィルタの検討}

Butterworthフィルタのカットオフ周波数を 0.313 0.516 cycle $/ \mathrm{cm}(0.20 \sim 0.33$ cycle/pixel $)$ まで $0.016 \mathrm{cycle} /$ $\mathrm{cm}(0.01 \mathrm{cycle} / \mathrm{pixel})$ ずつ変化させ，FBP法拈よび OSEM法それぞれについて再構成を行った。 OSEM法 の逐次近似回数，およびサブセット数については，11，1-2の奏験より得られた結果より最適と思われる組 み合わせを選択した。

\section{1-3-1 正常モデルによる心内腔容積の測定}

QGSにより心内腔容積を算出し，各カットオフ周波 
Table Processing time according to differences in iteration number and subset.

Processing time increased in proportion to iteration number.

\begin{tabular}{crrrrrrr}
\hline \hline \multirow{2}{*}{$\begin{array}{c}\text { Iteration } \\
\text { number }\end{array}$} & \multicolumn{7}{c}{ Subset (min'sec") } \\
\cline { 2 - 8 } & 1 & 2 & 3 & 5 & 10 & 15 & 20 \\
\hline 1 & $2^{\prime} 15^{\prime \prime}$ & $2^{\prime} 16^{\prime \prime}$ & $2^{\prime} 16^{\prime \prime}$ & $2^{\prime} 14^{\prime \prime}$ & $2^{\prime} 13^{\prime \prime}$ & $2^{\prime} 16^{\prime \prime}$ & $2^{\prime} 16^{\prime \prime}$ \\
2 & $3^{\prime} 20^{\prime \prime}$ & $3^{\prime} 25^{\prime \prime}$ & $3^{\prime} 25^{\prime \prime}$ & $3^{\prime} 25^{\prime \prime}$ & $3^{\prime} 25^{\prime \prime}$ & $3^{\prime} 25^{\prime \prime}$ & $3^{\prime} 31^{\prime \prime}$ \\
3 & $4^{\prime} 18^{\prime \prime}$ & $4^{\prime} 30^{\prime \prime}$ & $4^{\prime} 35^{\prime \prime}$ & $4^{\prime} 50^{\prime \prime}$ & $4^{\prime} 50^{\prime \prime}$ & $4^{\prime} 50^{\prime \prime}$ & $4^{\prime} 42^{\prime \prime}$ \\
5 & $6^{\prime} 40^{\prime \prime}$ & $6^{\prime} 47^{\prime \prime}$ & $6^{\prime} 54^{\prime \prime}$ & $6^{\prime} 50^{\prime \prime}$ & $6^{\prime} 50^{\prime \prime}$ & $6^{\prime} 55^{\prime \prime}$ & $7^{\prime} 05^{\prime \prime}$ \\
10 & $12^{\prime} 01^{\prime \prime}$ & $1^{\prime} 22^{\prime \prime}$ & $1^{\prime} 33^{\prime \prime}$ & $12^{\prime} 40^{\prime \prime}$ & $12^{\prime} 45^{\prime \prime}$ & $13^{\prime} 01^{\prime \prime}$ & $13^{\prime} 34^{\prime \prime}$ \\
FBP & $1^{\prime} 09^{\prime \prime}$ & & & & & & \\
\hline
\end{tabular}

matrix: $64 \times 64,960$ frames

数ごとの定量值の比較を行った。

\section{1-3-2 NMSEによる評価}

Butterworthフィルタのカットオフ周波数を $0.391 \mathrm{cycle} / \mathrm{cm}$ としてFBP法により再構成された短軸画 像を基準画像として，OSEM法の各カットオフ周波数 ごとの画像について，NMSEを算出した。

\section{1-4 臨床例による検討}

対象は安静時gated SPECTにより血流欠損のなかっ た13例である。 ${ }^{99 \mathrm{~m}} \mathrm{Tc}$ テトロフォスミン740MBq静注後 20分よりファントム実験と同様の収集条件にて撮像を 行った。FBP法の再構成は前処理フィル夕に Butterworthフィルタ(オーダ 8, カットオフ周波数 $0.391 \mathrm{cycle} / \mathrm{cm})$, 再構成フィルタはRamp フィルタを使 用した。OSEM法では1-1，1-2，1-3より得られた結 果を基に最適と思われる条件を設定し再構成を行っ た。それぞれ，QGSにより EDV，ESV，EFを算出 し，比較検討を行った，統計処理は平均值の $\mathrm{t}$ 検定㧍 よび単回帰分析にて行い， $\mathrm{p}<0.05 を$ 有意とした。

\section{2. 結 果}

\section{2-1 処理時間}

FBP法掞よびOSEM法の逐次近似回数とサブセット 数の違いによる処理時間の変化をTableに示す.FBP 法ではマトリクスサイズ $64 \times 64,960$ フレームのデー 夕を再構成するのに要する時間は約 1 分であったが, OSEM法では，逐次近似回数が 1 回の場合で 2 分 15 秒 程度かかり，以降逐次近似回数が 1 回増すたびに 1 分 強ずつ処理時間が長くなった。 OSEM法では，処理時 間は逐次近似回数にのみ依存し，サブセット数を増や しても大きな変化はみられなかった。
$2-2$ 逐次近似回数, サブセット数の検討

\section{2-2-1 心内腔容積の測定}

Fig. 2に前処理フィルタを使用しない場合の正常モ デル心筋ファントム，Fig. 3に下壁欠損モデル心筋フ アントム，Fig. 4に前処理フィルタを使用した場合の 正常モデル心筋ファントムの心内腔容積の測定值を示 す. OSEM法では，3 パターンすべてにおいて，更新 回数 (逐次近似回数 $\times$ サブセット数) が30以上の場合に 良好な結果が得られているが，どの逐次近似回数でも サブセット数が 20 になると值が低下する傾向がみられ た。特にサブセット数が15の場合に最も真值に近い值 となり，逐次近似回数が 2 から 3 程度で収束した。 また，最も高い值でも，FBP法に比べ低值を示した。

正常モデルにおけり 実測值の95mlに対しきわめて良好な結果が得られた が，下壁欠損モデルでは92mlと低值を示した．OSEM 法に打いても，前処理フィル夕を用いない場合の正常 モデルでの $93 \mathrm{ml}$ に対し，下壁欠損モデルでは $91 \mathrm{ml}$ あり，FBP法と同様に下壁欠損モデルでは心内腔谷積 が過小評価される傾向がみられた。

心内腔容積が算出されていないパラメータの組み合 わせは再構成時にエラーが生じ，再構成画像が得られ なかったものであるが，前処理フィルタを使用した場 合には処理が可能であった．しかしながら，更新回数 が増加しても，心内腔容積は一定值以上に増加するこ とはなかった。

\section{2-2-2 NMSEによる評価}

FBP法を基準とした場合のOSEM法の各パラメー夕 ごとのNMSEをFig. 5に示す.サブセット数が 1 から 10の場合は逐次近似回数が増加するのにしたがい減少 し，ほぼ一定の值に収束する傾向がみられた。サブセ ット数が15になると，逐次近似回数にかかわらず誤差 は急激に小さくなり，逆に20になると再び上昇した。 最も誤差が少ない組み合わせは逐次近似回数 2 , サブ 


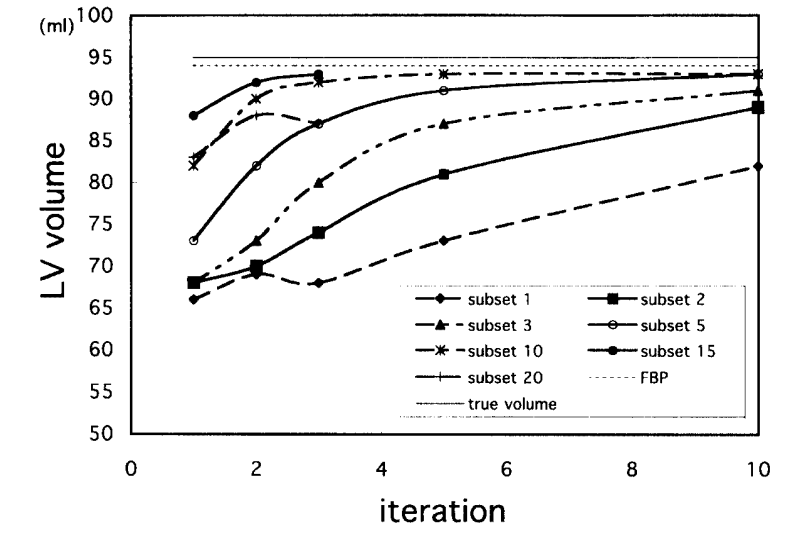

Fig. 2 Variation in LV volume according to differences in iteration number and subset in normal model myocardial phantom reconstructed without Butterworth filter.

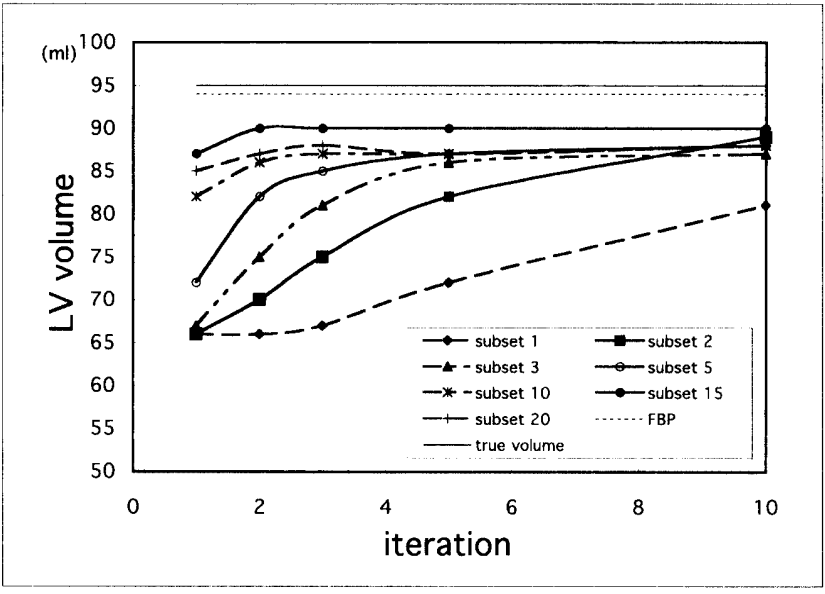

Fig. 4 Variation in LV volume according to differences in iteration number and subset in normal model myocardial phantom reconstructed with Butterworth filter.

セット数15であった。

\section{2-3 前処理フィルタの検討}

2-1，2-2より，OSEM法の逐次近似回数とサブセッ トの組み合わせとして，逐次近似回数 2, サブセット 数 15 を選択した。

\section{2-3-1 Butterworthフィルタのカットオフ周波数の変 化による心内腔容積の变化}

Butterworthフィルタのカットオフ周波数を变化させ た場合の心内腔容積の变化をFig.6に示す.FBP法， OSEM法ともカットオフ周波数が高くなるに従い心内 腔容積は高值となった. FBP法では0.400cycle/cm付近 で真值となり，その後ほぼ一定となった。OSEM法で も同様の傾向が認められたが，絶対值はFBP法よりも

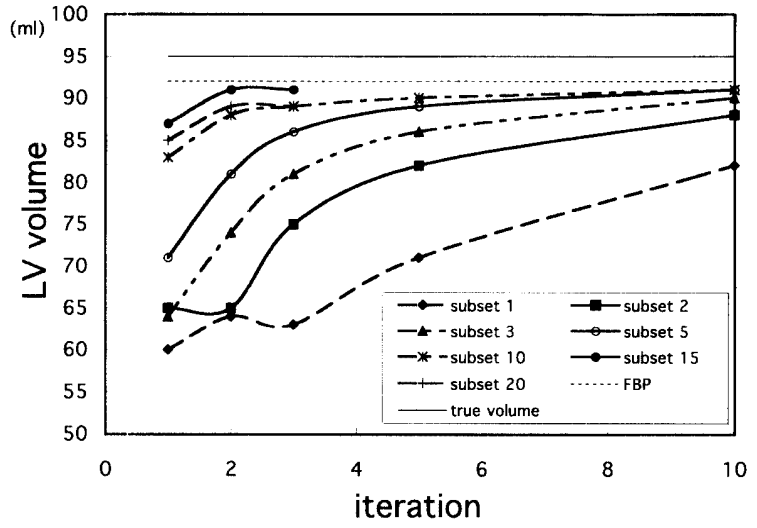

Fig. 3 Variation in LV volume according to differences in iteration number and subset in inferior defect model myocardial phantom reconstructed without Butterworth filter.

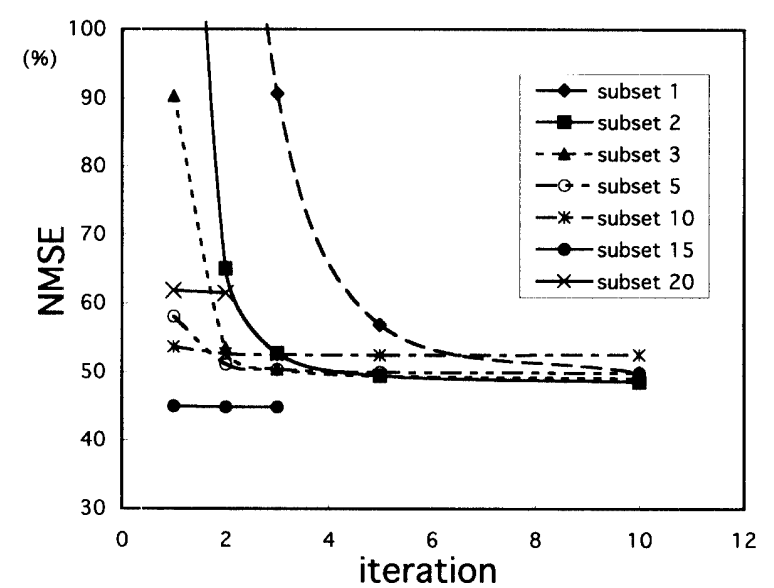

Fig. 5 Variation in normalized mean square error (NMSE) according to differences in iteration number and subset.

When the subset was 15 , error was minimized.

低く，カットオフ周波数を高くしても真值に到達する ことはなふった。

\section{2-3-2 Butterworthフィルタのカットオフ周波数の変 化によるNMSEの変化}

FBP法を基準画像とし，Butterworthフィルタのカッ トオフ周波数を変化させて再構成を行ったOSEM法に よる画像のNMSEの変化をFig. 7に示す。 0.438 cycle/ $\mathrm{cm}$ の場合にNMSEは最小となった。

\section{2-4 臨床:例による検討}

$2-1 ， 2-2 ， 2-3$ 上り OSEM法は逐次近似回数 2, サ ブセット数 15 , Butterworthフィルタのカットオフ周波 数を $0.438 \mathrm{cycle} / \mathrm{cm} に て$ 再構成を行った，対象となった 13例のFBP法とOSEM法によるEDV, ESV, EFの比 


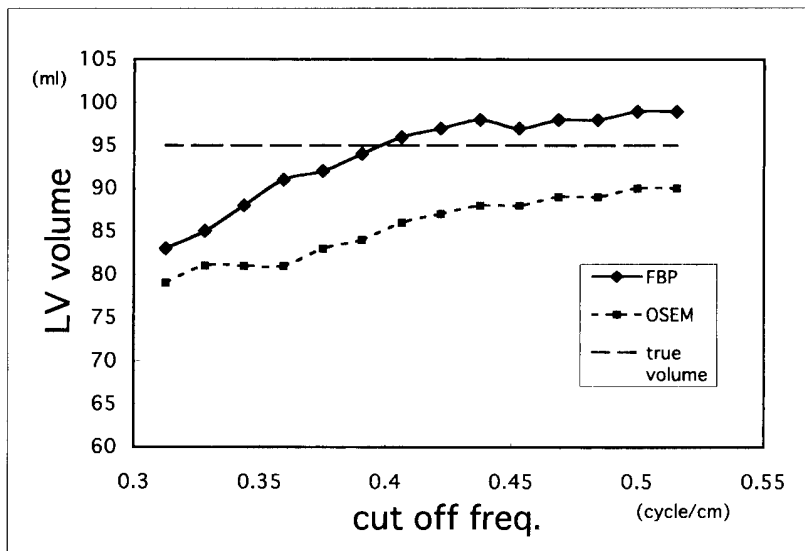

Fig. 6 Variation in LV volume according to differences in cutoff frequency of Butterworth filter.

Although true volume was reached at $0.400 \mathrm{cycle} /$ $\mathrm{cm}$ with the FBP algorithm, even if cutoff frequency was high, true volume was not reached by the OSEM algorithm.

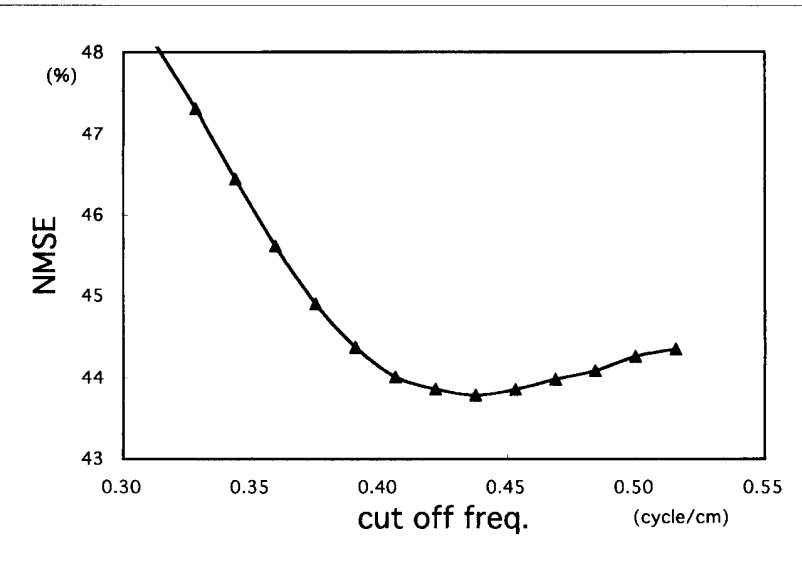

Fig. 7 Variation in normalized mean square error(NMSE) according to differences in iteration number and subset. When the cutoff frequency was $0.438 \mathrm{cycle} /$ $\mathrm{cm}$, error was minimized.

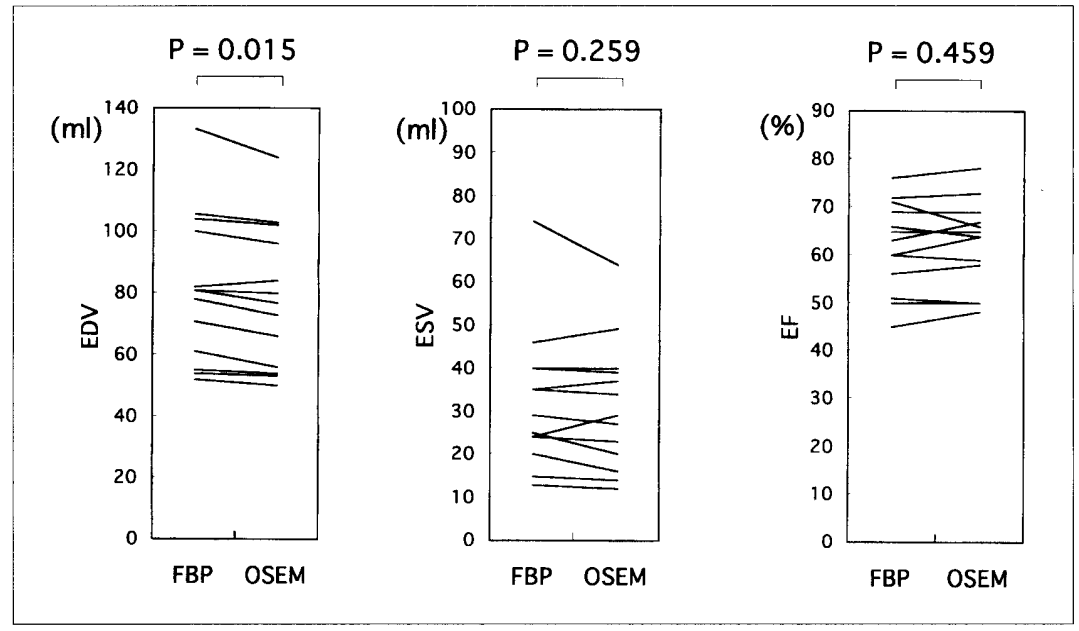

Fig. 8 Comparison of EDV, ESV, and EF between FBP and OSEM. A difference between FBP and OSEM was observed in EDV, but there were no significant differences between the two methods in ESV and EF.

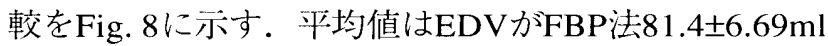
に対しOSEM法が78.3 $\pm 6.36 \mathrm{ml} ，$ ESVはそれぞれ $32.3 \pm 4.45 \mathrm{ml}, 31.1 \pm 4.15 \mathrm{ml}$, EFはそれぞれ $61.8 \pm 2.59$

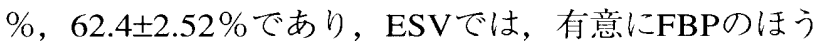
が高值を示したが $(\mathrm{p}=0.015), \operatorname{ESV}(\mathrm{p}=0.259), \mathrm{EF}$ ( $\mathrm{p}=0.459)$ では有意差はみられなかった。また，それ ぞれの相関をFig.9〜11に示す。相関はEDVが $\mathrm{y}=0.95 \mathrm{x}+1.25, \quad \mathrm{r}=0.99(\mathrm{p}<0.001), \quad \mathrm{ESV}$ が $\mathrm{y}=0.91 \mathrm{x}+1.76, \mathrm{r}=0.97(\mathrm{p}<0.001), \mathrm{EF}$ が $\mathrm{y}=0.94 \mathrm{x}+4.54$, $\mathrm{r}=0.96(\mathrm{p}<0.001)$ ときわめて高い相関を示した.

\section{3. 帮 察}

近年, OSEM法が一部装置で利用可能となり注目を
集めているが，パラメータの選択には明確な決定法が 存在しない。われわれは， ${ }^{99 \mathrm{~m}} \mathrm{Tc}$ 製剂を用いた心筋 gated SPECTに扔けるOSEM法の最適再構成条件を求 めるため，ファントム実験による基礎的検討および臨 床例により検討を行った。

心蔵ファントムを用いた心内腔容積の測定值は, FBP法を用いた場合Butterworthフィルタのカットオフ 周波数に依存する. GermanoらはButterworthフィルタ のカットオフ周波数が $0.390 \mathrm{cycle} / \mathrm{cm}$ で真值と一致した と報告している2．本邦に扔ける研究でも $0.400 \mathrm{cycle} /$ $\mathrm{cm}$ 程度で一定になるとの報告が多く11,12), 実際の臨床 に抢いても $0.400 \mathrm{cycle} / \mathrm{cm}$ 以上を用いるのが一般的であ るが，われわれの施設では16分割収集を行っているこ 


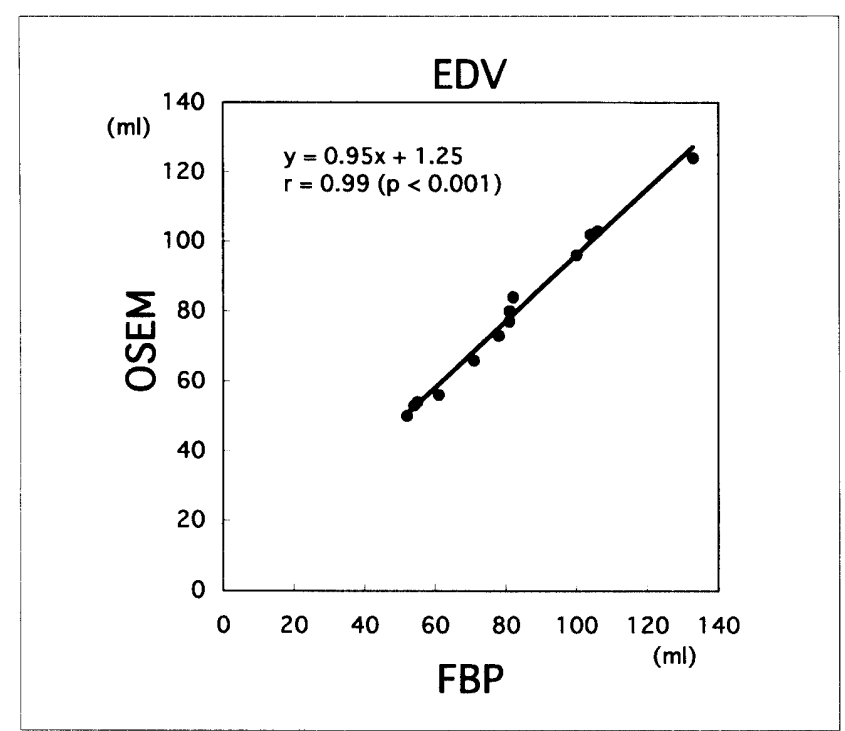

Fig. 9 Correlation between FBP and OSEM in EDV.

と，TEW法による散乱補正を行っていることなどを 考慮し，視覚評価も併せてFBP法におけるカットオフ 周波数として0.391 cycle/cmを用いて扔り，今回の検討 における基準画像としてもこの画像を採用した.ファ ントム実験による心内腔容積抢よびNMSEの結果では OSEM法の再構成パラメータは, 更新回数30回以上で サブセット数15以下の場合に良好な結果が得られた が，このなかで最も計算時間の短くなる組み合わせは 逐次近似回数 2 , サブセット数 15 であった. OSEM法 に㧍ける再構成パラメータを選択するうえで重要とな る要素の一つに処理時間の問題がある. OSEM法は逐 次近似回数に比例し処理時間が長くなり，最も短い逐 次近似回数が 1 回の場合でもFBP法の倍の時間を要す る. 特にgated SPECTの場合処理フレーム数が多くな るため, 処理時間の延長は日常の業務において支障と なり，逐次近似回数は極力少なく設定する必要があ る.

OSEM法に扔ける前処理フィルタの違いによる心内 腔容積の変化はFBP法に比べ緩やかではあるが同様の 傾向にあり，カットオフ周波数が高くなるに従い増加 し， $0.400 \mathrm{cycle} / \mathrm{cm}$ 程度以上になると大きな変化を認め なかった. NMSEの結果ではFBP法に比べ高めのカッ トオフ周波数 $(0.438 \mathrm{cycle} / \mathrm{cm})$ で鿁差が最小となった. OSEM法ではFBP法に比べ統計ノイズが強調されない ため ${ }^{8)}$, 視覚的にも, ある程度カットオフ周波数を高 くしても画質の劣化は少ないものと思われる.

以上の結果より，われわれは99m $\mathrm{Tc}$ 製㓣を用いた心 筋gated SPECTに扔けるOSEM法の最適再構成条件と して, プロジェクション数が60の場合, 逐次近似回数 2, サブセット数 15 , Butterworthフィルタのカットオ フ周波数 $0.438 \mathrm{cycle} / \mathrm{cm}$ 推奨する.

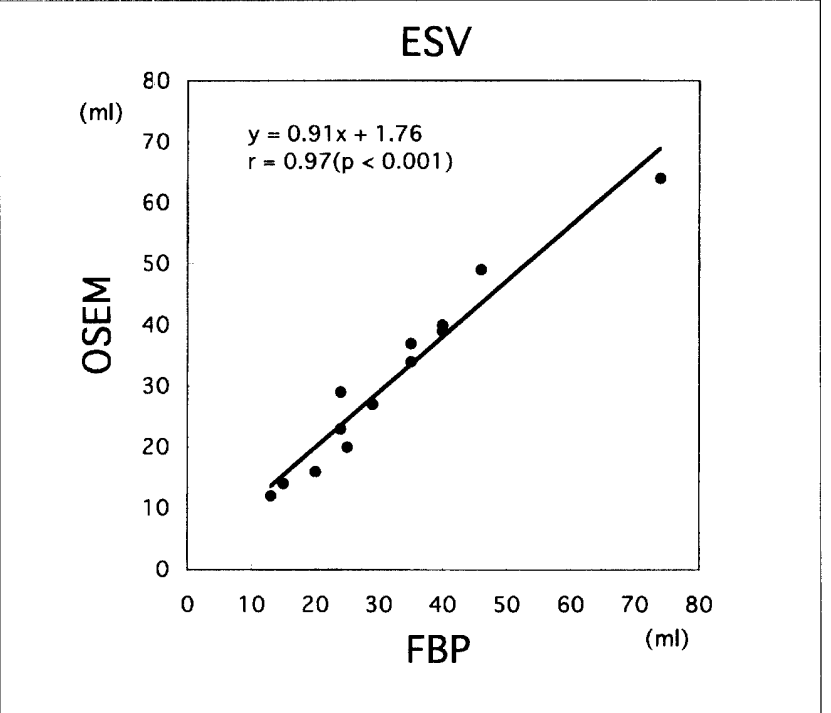

Fig. 10 Correlation between FBP and OSEM in ESV.

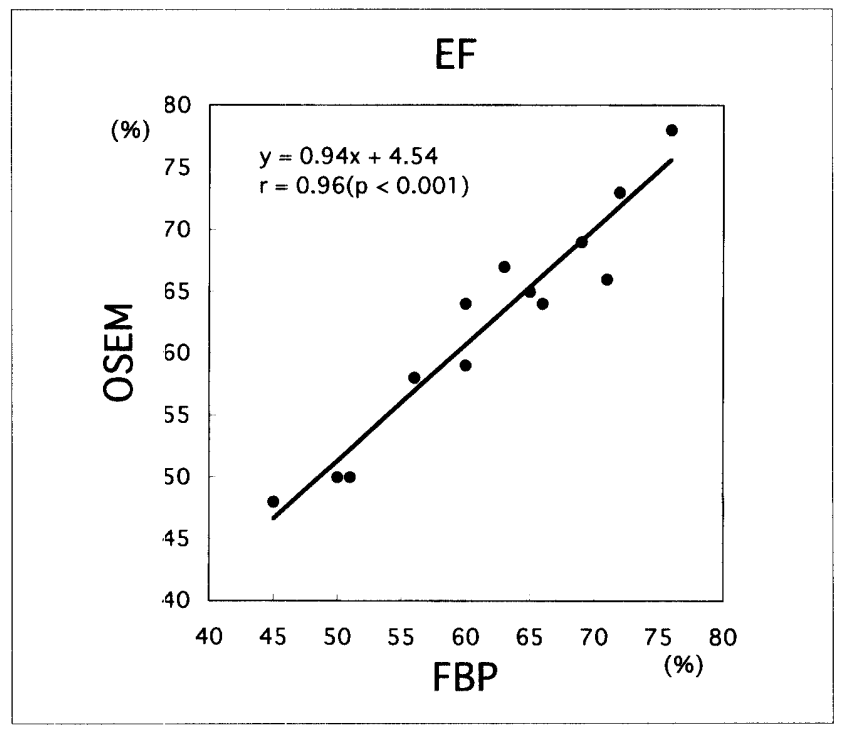

Fig. 11 Correlation between FBP and OSEM in EF.

FBP法での心筋ファントムの心内腔容積は94mlと真 值の95mlに対してきわめて近い值を示している。これ に対し，OSEM法では前処理フィルタを使用せずに再 構成を行った場合, 最も高い値でも $93 \mathrm{ml}$ とFBP法には 及ばなかった。前処理フィルタをかけることにより， さらにこの值は低くなり，現状におけるOSEM法の限 界が認められた。また，QGSによる定量では，広範 な欠損部位が存在する場合過小評価される傾向にあ るがい，これはOSEM法を用いて再構成を行っても改 善されなふった。今回は完全欠損モデルにて検討を行 ったため，QGSの自動輪郭抽出処理の影響のみが反映 されたためであり，実際の臨床例においてみられる， わずかながら集積が存在するような場合には，再構成 
法の違いによる久損の範囲と程度の差が生じる可能性 があり，今後検討が必要になるものと思われる.

OSEM法の再構成画像は，1 サブセット内のデータ 数, サブセットの組み方, 計算順番により影響を受け る $^{13,14)}$ 。今回の検討の結果では, サブセット数が15の 場合に心内腔容積およびNMSEの結果が良好であり， 逆にサブセット数が20になると悪化した。プロジェク ション数が60の場合, サブセット数が 20 であれば 1 サ ブセット当たりに含まれるデー夕数は 3 となり，推定 に寄与するデー夕数が不足するために推定の䛊差が大 きくなるものと思われる。したがって，OSEM法に拧 けるサブセット数は，1 サブセット当たりのデータ数 が 4 以上になるように設定する必要があるものと思わ れる。また，サブセット数が15の場合に結果が特に良 好であった理由に関しては，サブセットの組み方およ び計算順番の影響が挙げられる。OSEM法ではサブセ ットをプロジェクションの方向順に計算せずに，でき るだけ角度の離れたデー夕を選択して計算を行うこと により，良好な画像を得ることが可能となる13,14)。サ ブセットの組み方抢よび計算順番については任意性が あり，今回使用したソフトウェアについても詳細は明 らかではないが，最大角度離すようにサブセットを組 んでいると仮定すると, サブセット数が15すなわち， 1 サブセット内のデータ数が 4 の場合は90離れたデ ー夕を用いて計算を行っていることになり，投影デ一 夕の独立性も保たれることから，良好な結果が得られ たものと推測される。

今回の検討では，TEW法による散乱補正を行い， また，前処理フィル夕についても言及した。最尤推定 法は投影データがポアソン分布に従うことから導か れた式であり，投影データの減算処理を行った場 合，ポアソン分布にはならないため厳密な推定を行 えない15). 雑音を含まない画像では更新回数を増すこ とにより，再構成画像は収束していくが，われわれが 日常用いる臨床画像に扩いては, 散乱線掞よび多量の 雑音を含んで扔りその収束性が保証されないは梳。した がって現状で臨床のSPECT画像においてOSEM法を応 用する場合，まず，TEW法など複数ウィンドを設定 し散乱線を推測し投影データから減算することにより 散乱補正を行い，さらに低域通過型フィル夕を使用し 雑音を除去することにより定量性および画質を保つ必 要が生じる。松岡ら ${ }^{16)}$ は201T1による検討において, 減 算処理による散乱補正と，減算処理を行わない場合を 比較しコントラストに差がないと報告している.

また，今回の結果に扔いて，心内腔容積が高いとい
うことは，コントラストの高い画像が得られたという こと, NMSEが小さいという結果はFBPの画像に近い 画像が得られたということであり，逐次近似回数 2, サブセット数15という再構成パラメータが，精度の高 い推定を行った，言い換えれば真の画像に近い再構成 を行ったということを直接支持するものではない．し かしながら，臨床例でのFBP法との相関が高いことか ら考えても，現状でFBP法に代わってOSEM法を用い る場合には，今回得られた再構成条件は，臨床上は支 障がないものと考えられる.

OSEM法にはさまざまな利点があるが，現状での臨 床応用に扔いてはアーチファクトの軽減のほかに, 統 計ノイズが強調されにくいため ${ }^{8)}$ ，分割収集により1 フレーム当たりのカウント数が少ないgated SPECTに 拀いてED，ES画像を作成する場合，視覚的に滑らか な画像となることの2点に絞られる。一方，今回の結 果からもFBP法に比ベコントラストが悪くなる場合も あり，われわ机も現状に扔いては，胆囊からのアーチ ファクトにより下壁欠損の鑑別が困難な場合に限り， 臨床医のコンセンサスを得たうえでFBP法の結果に付 してOSEM法の画像を供するにとどめている。しか L, OSEM法の最大の利点は, 散乱・吸収 ·分解能補 正を計算過程に組み込めることにあり，これらの補正 アルゴリズムの確立㧍よびデー夕処理装置の高速化に より臨床応用が可能となれば，画質，定量性とも向上 することが予想される。本研究は現状でのOSEM法の 臨床応用を対象として再構成条件の検討を行ったが, さまざまな補正を組み込めばまた最適条件は変化する ものであり，再検討を行っていくうえで基礎デー夕に なるものと思わ机る。

\section{4. 結 論}

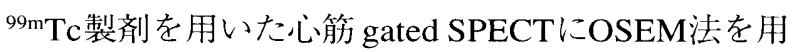
いるため，ファントムによる基礎実験および臨床例に 扔いて最適再構成条件について検討を行った。ファン トム実験による心内腔容積, NMSEの結果から, OSEM法に打ける最適再構成条件として, プロジェク ション数が 60 の場合, 逐次近似回数 2 , サブセット数 15, Butterworthフィルタのカットオフ周波数 $0.438 \mathrm{cycle} / \mathrm{cm}$ を推奨する. OSEM法による心内挖容積 はFBP法に比べ低い值であった，QGSにより求めた臨 床例に㧈ける定量值の相関はEDVが $\mathrm{y}=0.95 \mathrm{x}+1.25$, $\mathrm{r}=0.99(\mathrm{p}<0.001), \quad E S V$ が $\mathrm{y}=0.91 \mathrm{x}+1.76, \mathrm{r}=0.97$ $(\mathrm{p}<0.001), \mathrm{EF}$ が $\mathrm{y}=0.94 \mathrm{x}+4.54, \mathrm{r}=0.96(\mathrm{p}<0.001)$ とき わめて高い相関を示した。 


\section{参考文献}

1) Germano G, Kavanagh PB, Su HT, et al.: Automatic reorientation of three-dimensional, transaxial myocardial perfusion SPECT images. J Nucl Med, 36, 1107-1114, (1995).

2) Germano G, Kiat H, Kavanagh PB, et al.: Automatic quantification of ejection from gated myocardial perfusion SPECT. J Nucl Med, 36, 2138-2147, (1995).

3) Germano G, Erel J, Lewin H, et al.: Automatic quantification of regional myocardial wall motion and thickening from gated technetium-99m sestamibi myocardial perfusion singlephoton emission computed tomography. J Am Coll Cardiol, 1360-1367, (1997).

4) Germano G, Chua T, Kiat H, et al.: A quantitative phantom analysis of artifacts due to hepatic activity in technetium-99m myocardial perfusion SPECT studies. J Nucl Med, 35, 356359, (1994).

5) 柳沢正道：SPECTにおけるアーチファクトとその対策一臨 床の立場から $(2)$ - . 日本核笑学技術学会第15间総会シン ポジウム(1)，1995-7，核医学技術，15(4)，325-327， (1995).

6) Bruyant PP, Sau J, and Mallet J : Streak artifact reduction in filtered backprojetion using a level line-based interportion method. J Nucl Med, 41, 1913-1919, (2000).

7) Hudson HM and Larkin RS: Accelerated image reconstruction using ordered subsets of projection data. IEEE Trans Med Image MI, 13, 601-609, (1994).

8）篠原庄行, 國安㞣大，林 䯩樹，他：ML-EMアルゴリズ 公の核医学:のの忍朋。放医物理，19(3)，174-183，
(1999).

9）怞智明，市川和弘，大堀克已，他：統計的な画像再構成 法の臨床応用への可能性 2. OS-EM法の心筋SPECTへの 灾用。 H本医放会誌驸録，60(7)，16-19，(2000)。

10) Blocklet D, Seret A, Popa N, et al.: Maximum-likelihood reconstruction with ordered subsets in bone SPECT. J Nucl Med, 40, 1978-1984, (1999).

11）木卜体并，南部一郎，遠山淳子，他：心電闵同期99m Tc 心 筋血流SPECTに㧈ける応哀容積值，駆出率自動算出の検討 ーファントムを用いた基礎的評価一。核医学，35，7783, (1998).

12）片㴊哲的，西村寺弘，西原隆生，他：Gated心筋SPECTに よる心機能の定量的評怵 $\sim \mathrm{QGS}$ の有用性一，映像情報，31 (12), 707-711, (1999).

13）尾川浩 - 高橋旨晃：Ordered Subsetsを用いた期待值最大 化法における投影データの選択と計算順番が再構成画像に

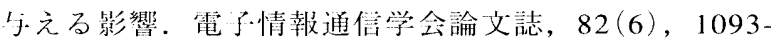
$1099,(2000)$.

14）尾川浩一：OS-EMによる荬像再構成. 放医物理，19(3)， 184-192, (1999).

15) Lange $K$ and Carson R: EM reconstruction algorithms for emission and transmission tomography. J Comput Assist Tomogr. 8, 306-316, (1984).

16）松阔 件, 篠原店行, 山本智朗, 他：OS-EMアルゴリズム による2011 T1心筋盉流SPECTの散乱・吸収補正。日本医放会 誌, 58(13), 751-757,(1998).

\section{図表の説明}

Fig. 1 下壁欠撌モデル心筋ファントムのシェーマ.

Fig. 2 前処理フィルタを使朋しない場命の正常モデル心筋ファントムに㧍ける逐次近似回数とサブセット数の違いによる心内腔 容皘.

Fig. 3 前処理フィルタを使用しない場令の下壁火損心筋ファントムに扔ける逐次近似回数とサブセット数の違いによる心内腔容 積.

Fig. 4 前処理フィルタを使用した場合の正常モデル心筋ファントムにおりる逐次近似回数とサブセット数の違いによる心内腔容 積.

Fig. 5 FBP法に刘するOSEM法の逐次近似回数とサブセット数の違いによる䛊差.

サブセット数が15の埸命に䛊产が最小となった。

Fig. 6 Butterworthフィルタのカットオフ周波数の違いによる心内腔率積の変化. FBP法では0.400 cycle/cm付近で真值に達するが, OSEM法ではカットオフ周波数を高くしても真值には達しなかった。

Fig. 7 FBP法に対するOSEM法のバターワースフィルタのカットオフ䧓波数の違いによる誤差. $0.435 \mathrm{cycle} / \mathrm{cm}$ で䛊差が最小とな つた.

Fig. 8 臨床例におけるFBP法とOSEM法のEDV, ESV, EFの比較. EDVではOSEM法のほうが有意に低俻をホしたが，ESV，EFでは有意㾦はみられなかった。

Fig. 9 臨休例に扮けるFBP法とOSEM法のEDVの相関。

Fig. 10 臨床例におけるFBP法とOSEM法のESVの相関.

Fig. 11 郮休例に㧈けるFBP法とOSEM法のEFの相関。

Table FBP法抢よびOSEM法の逐次近似回数とサブセット数の違いによる処理時間の変化. 逐次近似回数に比例して処理時間が長くなった。 